\title{
Geochronology of the middle Eocene Purple Bench locality (Devil's Graveyard Formation), Trans-Pecos Texas, USA
}

\author{
Amy L. Atwater, Kelly D. Thomson, E. Christopher Kirk, \\ Meaghan Emery-Wetherell, Logan Wetherell, and Daniel F. Stockli
}

\begin{abstract}
Purple Bench is a middle Eocene fossil locality in the Devil's Graveyard Formation of the Trans-Pecos region of West Texas. In addition to yielding a range of taxa characteristic of the Uintan North American Land Mammal Age, the Purple Bench locality is noteworthy in documenting a number of endemic species that are known only from the site. Despite the Uintan character of the mammalian fauna, the absolute age of Purple Bench is a matter of debate. This uncertainty stems from the wide interval of time encompassed by current radiometric dates bracketing the Purple Bench locality and from conflicting magnetostratigraphic correlations in the Devil's Graveyard Formation. This study constrains the absolute age of the Purple Bench locality through detrital zircon U-Pb geochronological analyses. For these analyses, 147 new detrital zircon U-Pb ages were collected from five tuffaceous sandstones and reworked tuff horizons and analyzed via Laser Ablation Inductively Coupled Plasma Mass Spectrometry (LA-ICP$\mathrm{MS}$ ). These new detrital zircon $\mathrm{U}-\mathrm{Pb}$ geochronological analyses suggest a maximum depositional age of $43.7+0.8 /-0.2$ Ma for the Purple Bench tuff, a significant marker horizon immediately below the Purple Bench locality. These new maximum depositional age dates presented here provide constraints on the true depositional age of the lower and middle members of the Devil's Graveyard Formation, bringing clarity to the previously ambiguous age of the fossil-bearing Purple Bench locality. The age constraints presented here also aid the characterization of the temporally and spatially variable Uintan North American Land Mammal Age.
\end{abstract}

Amy L. Atwater. Museum of the Rockies, Montana State University, Bozeman, Montana 59717, USA. amy.atwater@montana.edu

Kelly D. Thomson. Department of Geological Sciences, Jackson School of Geosciences, University of Texas at Austin, Austin, Texas, USA. kellydthomson@utexas.edu

E. Christopher Kirk. Department of Anthropology and Jackson School Museum of Earth History, University of Texas at Austin, Austin, Texas, USA. eckirk@austin.utexas.edu Meaghan Emery-Wetherell. Department of Geological Sciences, Central Washington University, Ellensburg, Washington, USA. meaghan.wetherell@gmail.com

Atwater, Amy L., Thomson, Kelly D., Kirk, E. Christopher, Emery-Wetherell, Meaghan, Wetherell, Logan, and Stockli, Daniel F. 2020. Geochronology of the middle Eocene Purple Bench locality (Devil's Graveyard Formation), Trans-Pecos Texas, USA. Palaeontologia Electronica 23(1):a06. https://doi.org/10.26879/993

palaeo-electronica.org/content/2020/2898-devil-s-graveyard-u-pb-dating 
Logan Wetherell. Department of Geological Sciences, Central Washington University, Ellensburg, Washington, USA. Irwetherell@gmail.com

Daniel F. Stockli. Department of Geological Sciences, Jackson School of Geosciences, University of Texas at Austin, Austin, Texas, USA. stockli@jsg.utexas.edu

Keywords: Uintan NALMA, detrital zircon geochronology, Eocene, U-Pb dating, Tornillo Basin

\section{INTRODUCTION}

The Devil's Graveyard Formation (DGF) includes $\sim 500 \mathrm{~m}$ of interbedded volcaniclastic sediments and overbank paleosols with discontinuous isolated channels deposited in the Tornillo Basin of southwest Texas (Figure1; Stevens et al., 1984; Lehman, 1991). Paleontological research in the DGF undertaken in the 1970 s by J.A. Wilson, J.B. Stevens, and M.S. Stevens led to the discovery of numerous fossil vertebrate localities spanning the middle to late Eocene (Stevens et al., 1984a; Stevens et al., 1984b; Wilson, 1986). Within the DGF, the Purple Bench locality (TMM 41672) has been the subject of intensive collecting efforts since 2005. This locality has yielded an abundant collection of middle Eocene vertebrate fossils (Table 1). The Purple Bench locality occurs at the transition between the lower and middle members of the
DGF as defined by Stevens et al. (1984). The fossil assemblage from the Purple Bench locality is noteworthy for including genera that are typical of the Uintan North American Land Mammal Age (NALMA) (e.g., Amynodon, Epihippus, Leptoreodon, and Protoreodon; Gunnell et al., 2009; Robinson et al., 2004) as well as a range of taxa that are currently known only from the site (Table 1). These endemic taxa from Purple Bench include the artiodactyl Texodon (West, 1982), the primates Diablomomys and Mescalerolemur (Williams and Kirk, 2008; Kirk and Williams, 2011), and the amphisbaenian Solastella (Stocker and Kirk, 2016).

\section{Geology}

The Trans-Pecos region of Texas encompasses the southern-most extent of the Rocky

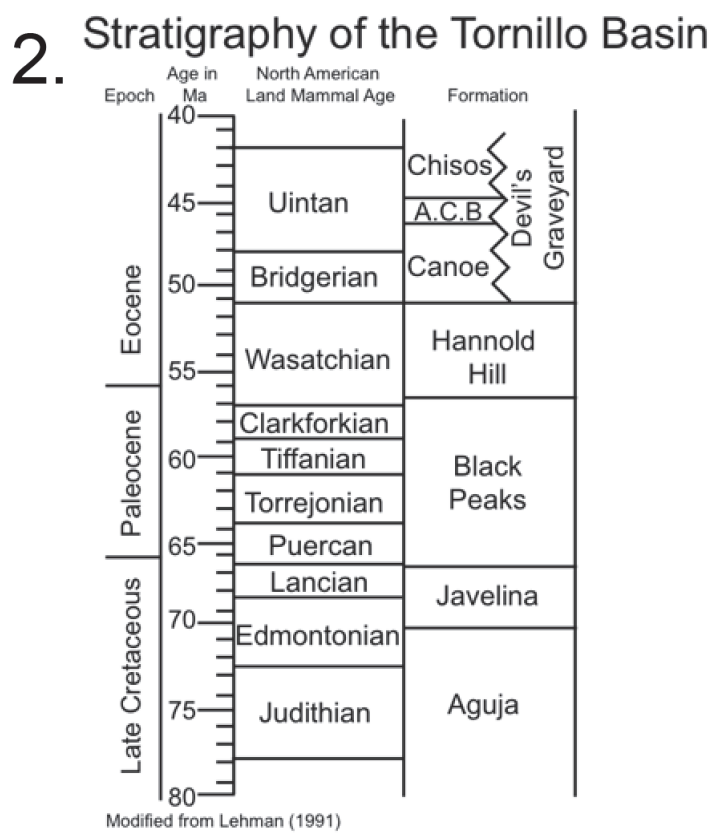

FIGURE 1. 1.1 Map of the Tornillo Basin (modified from Atchley et al., 2004 after Lehman, 1986). Star indicates location of the Devil's Graveyard Formation exposures examined in this study. 1.2. Stratigraphy of the Tornillo Basin and the related North American Land Mammal Ages. A.C.B. = Alamo Creek Basalt (Modified from Lehman, 1991). 
TABLE 1. Revised faunal list for the Purple Bench Locality (TMM 41672). Compiled from (West, 1982; Gustafson, 1986; Wilson, 1986b; Walton, 1993; Williams and Kirk, 2008; Kirk and Williams, 2011; Stocker and Kirk, 2016; Kirk, 2018). ${ }^{*}=$ endemic taxon known only from Purple Bench.

\begin{tabular}{|c|c|c|}
\hline HIGHER TAXON & SPECIES & SOURCE \\
\hline Amphisbaenia & Solastella cookei* & Stocker and Kirk, 2016 \\
\hline Serpentes & Alethinophidia sp. indet & Stocker and Kirk, 2016 \\
\hline Anguimorpha & Glyptosaurinae sp. indet. & Stocker and Kirk, 2016 \\
\hline Eutheria, incertae sedis & Simidectes magnus & Wilson, 1986 \\
\hline Artiodactyla & Leptoreodon edwardsi & Wilson, 1986 \\
\hline Artiodactyla & Leptoreodon major & Wilson, 1986 \\
\hline Artiodactyla & ? Malaquiferus sp. & Wilson, 1986 \\
\hline Artiodactyla & Protoreodon petersoni & Wilson, 1986 \\
\hline Artiodactyla & Protoreodon pumilus & Wilson, 1986 \\
\hline Artiodactyla & ?Protylopus sp. & Wilson, 1986 \\
\hline Artiodactyla & Texodon meridianus* & West, 1982 \\
\hline Carnivora & ? Uintacyon scotti & Gustafson, 1986 \\
\hline Condylarthra & Hyopsodus uintensis & West, 1982 \\
\hline Perissodactyla & Epihippus uintensis & Wilson, 1986 \\
\hline Perissodactyla & ? Triplopus sp. & Wilson, 1986 \\
\hline Primates & Diablomomys dalquesti* & Williams and Kirk, 2008 \\
\hline Primates & Mescalerolemur horneri* & Kirk and Williams, 2011 \\
\hline Primates & Omomyinae, gen. nov.* & Kirk, 2018 \\
\hline Rodentia & Leptotomus sp. & Wilson, 1986 \\
\hline Rodentia & Microparamys sp. & Wilson, 1986 \\
\hline Rodentia & Mysops sp. & Wilson, 1986 \\
\hline Rodentia & Paramys cf. $P$. delicatior & Wilson, 1986 \\
\hline Rodentia & Pauromys sp. indet. & Walton, 1993 \\
\hline Rodentia & Prolapsus sp. & Wilson, 1986 \\
\hline Rodentia & Thisbemys sp. & Wilson, 1986 \\
\hline
\end{tabular}

Mountains in the United States and preserves southern Laramide foreland basin environments from the Eocene (Figure 1; Stevens et al., 1984a; Wilson, 1986a; Runkel, 1990; Lehman et al., 2018). Exposures of the DGF occur entirely within the Tornillo Basin and therefore the southern-most intermontane Laramide basin in the United States (Lehman, 1991). Crustal shortening of the Chihuahua fold-thrust belt and flexural subsidence of the Tornillo Basin occurred from the late Cretaceous to the early Eocene (Lehman, 1991). Middle Eocene deposits of the DGF unconformably overlie Cretaceous deposits (Wilson, 1986b; Runkel, 1990). The source of volcaniclastic sediments of the DGF and time-correlated Canoe and Chisos formations in the Big Bend region potentially originated in two volcanic centers, one from the Sierra Madre Oriental in Mexico, and one from the Christmas Mountains volcanic center (Stevens et al., 1984a; Swanson and McDowell, 1984; Henry and Price,
1989; Runkel, 1990; Nieto-Samaniego et al., 1999; Lawton et al., 2009; Lehman et al., 2018). The preservation of a long continuous stratigraphic record in the Trans-Pecos area makes this region important for understanding the changes in mammalian faunas from the Uintan through the Chadronian NALMAs (Prothero, 1996; Robinson et al., 2004; Williams and Kirk, 2008; Gunnell et al., 2009).

\section{Existing Relative and Absolute Age Constraints}

Fossils from the Purple Bench locality were included in the Serendipity local fauna described by Wilson (1986). Comparisons to other North American faunas of this time period place the Serendipity local fauna in the late Uintan (Ui3) NALMA, as revealed by the presence of the perissodactyl Epihippus uintensis and the artiodactyls Protoreodon petersoni and P. pumilus (Table. 1; Robinson et al., 2004; Wilson and Stevens, 1986b; 
Murphey et al., 2018). According to Robinson et al. (2004), the Uintan NALMA spans a time interval between approximately 46.3 - 41.3 Ma. Published radiometric dates bracketing the Purple Bench locality were derived from $\mathrm{K} / \mathrm{Ar}$ analysis of biotiterich tuffs dated to $43.9 \pm 0.9 \mathrm{Ma}$ ( $2 \mathrm{~s}$ standard error) from the lower portion of the lower member, and to $42.7 \pm 1.6 \mathrm{Ma}$ (2s standard error) from the upper portion of the middle member of the DGF (Stevens et al., 1984b; Walton, 1992). The imprecision of these dates places the fossil assemblage from the Purple Bench locality within a 3.6 Ma time interval (i.e., 41.1 - $44.7 \mathrm{Ma}$ ). Additionally, the Purple Bench locality occurs stratigraphically above a series of localities in the lower member of the DGF (Figure 2) that have yielded a mammalian fauna distinctive of the early Uintan (Ui1b) NALMA (Campisano et al., 2014; Stocker and Kirk, 2016). Recent biotite and sanidine ${ }^{40} \mathrm{Ar} /{ }^{39} \mathrm{Ar}$ radiometric dating of volcanic tuffs constrain the Ui1b Whistler Squat Quarry of the DGF to be between $45.04 \pm$ 0.05 and $44.88 \pm 0.04 \mathrm{Ma}$ (2s standard error; biotite and sanidine respectively; Campisano et al., 2014). Mammalian taxa characteristic of the Duchesnean NALMA occur stratigraphically higher than the Purple Bench locality in the DGF (Wilson and Stevens, 1986; Robinson et al., 2004). The beginning of the Duchesnean NALMA can be no later than $39.75 \pm 0.04 \mathrm{Ma}$ (2s standard error), based on biotite ${ }^{40} \mathrm{Ar} / 39 \mathrm{Ar}$ dates from the type section of the Duchesnean in eastern Utah (Prothero and Berggren, 2014; Murphey et al., 2018). These factors constrain the absolute age of fossils from the Purple Bench locality to be between $41-45 \mathrm{Ma}$.

Two different research groups have previously attempted to further clarify the absolute ages of fossil localities in the DGF through magnetostratigraphic measurements and correlations, but these analyses produced conflicting interpretations. Walton (1992) correlated the middle member of the DGF to the C20R-C20N Chron transition, suggested an absolute age of $43.43 \mathrm{Ma}$ for the Purple Bench locality (recalibrated to GST2012; Gradstein et al., 2012). Prothero (1996) indicated that the Purple Bench locality is actually within the $\mathrm{C} 18 \mathrm{r}$ Chron and is therefore younger ( $41 \mathrm{Ma}$; recalibrated to GST2012; Gradstein et al., 2012) than that estimated by Walton ( 43.43 Ma; Walton, 1992).

These differing interpretations of DGF magnetostratigraphic section, combined with the broad time interval encompassed by bracketing radiometric dates, have led to uncertainty regarding the absolute date of the faunal samples from the Pur- ple Bench locality. While absolute dating of tuff horizons would be ideal, detrital zircon U-Pb dating is a powerful method that may be used to constrain the maximum depositional age of stratigraphic horizons in areas like the DGF that are characterized by active volcanism (Dickinson and Gehrels, 2009; Johnstone et al., 2019; Coutts et al., 2019). Although post-eruption reworking of sediment and interbedded tuffs leads to mixed zircon age components in sediments collected from a single stratigraphic horizon, the youngest age mode recovered by detrital zircon $\mathrm{U}-\mathrm{Pb}$ dating should represent the syn-depositional volcanic age mode and hence can be used to constrain an upper bound estimate of the true depositional age of the sediment (Dickinson and Gehrels, 2009). The aim of this study is to constrain the true depositional age of the Purple Bench locality via detrital zircon U-Pb dating of samples that stratigraphically bracket the fossilbearing horizon.

\section{Abbreviations}

Argon-Argon ( $\left.{ }^{40} \mathrm{Ar} /{ }^{39} \mathrm{Ar}\right)$; Devil's Graveyard Formation (DGF); Kilograms (kg); Laser Ablation Inductively Coupled Plasma Mass Spectrometry (LAICP-MS); Maximum Depositional Age (MDA); North American Land Mammal Age (NALMA); Potassium-Argon (K/Ar); True Depositional Age (TDA); Two sigma (2s); University of Texas at Austin (UT); Uranium-lead (U-Pb).

\section{MATERIALS AND METHODS}

Five tuffaceous sandstone horizons were sampled from exposures of the DGF at Midwestern State University's Dalquest Desert Research Station in Brewster County, Texas. The five samples (2-3 kg) were collected from fine- to mediumgrained tuffaceous sandstones that are stratigraphically adjacent to fine-grained fossil horizons associated with the following localities (Figure 2): Rhino's Loaf (TMM 45914), Krister Step (TMM 44174), Purple Bench (TMM 41672), and Peaches (TMM 46513). Two separate sublocalities (TMM 41672, sublocalities 8 and 19) were sampled for Purple Bench locality because this site encompasses multiple discontinuous exposures along the south fork of the Alamo de Cesario Arroyo for a distance of about $1.3 \mathrm{~km}$. These distinct fossiliferous exposures are designated as separate sublocalities of TMM 41672, but occur at approximately the same stratigraphic horizon. The sample used for detrital zircon U-Pb dating at Purple Bench sublocality 8 was collected from the Purple Bench tuff marker horizon itself, which occurs stratigraphically 


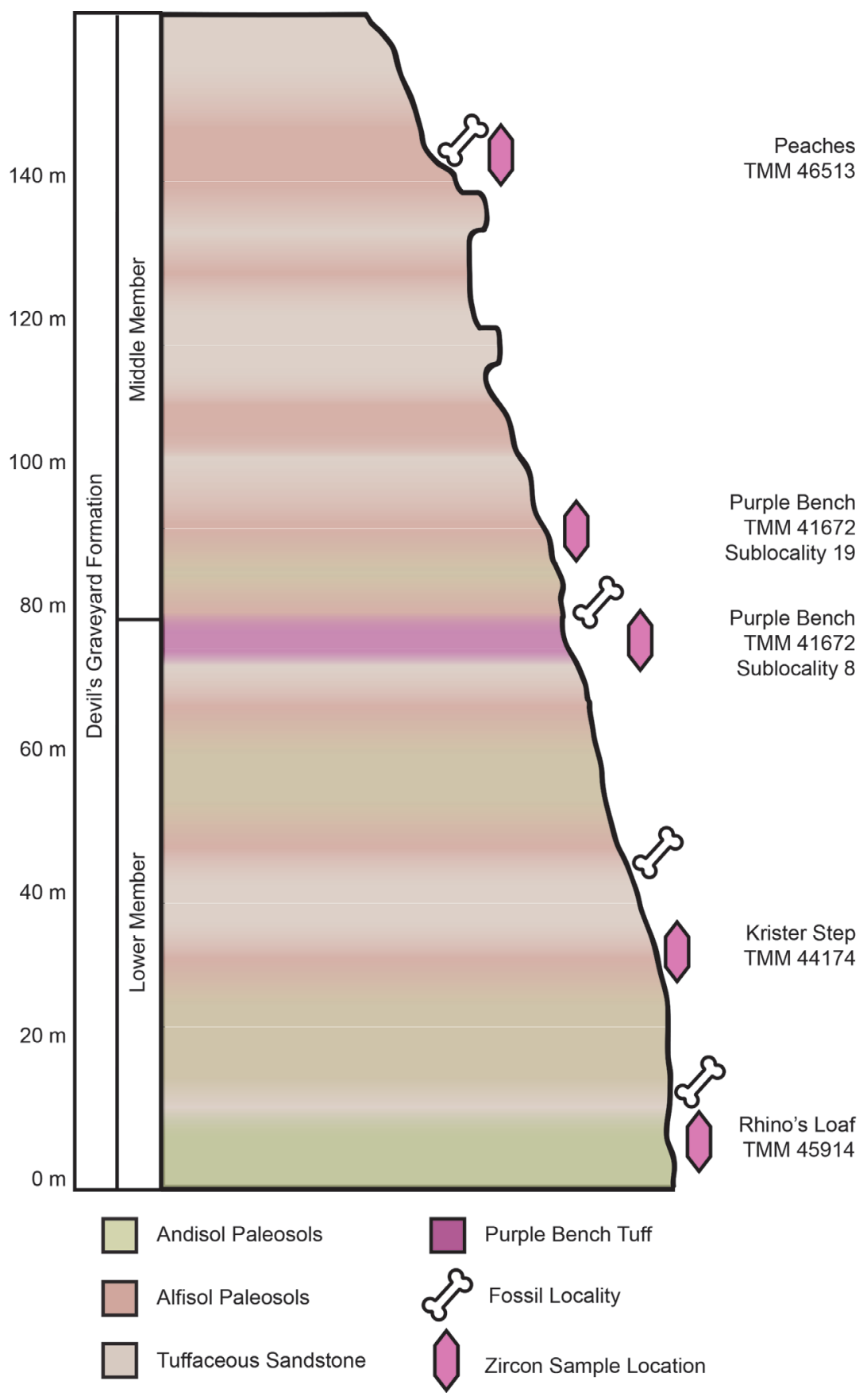

FIGURE 2. Generalized stratigraphic column of the lower and middle members of the Devil's Graveyard Formation. Symbols denote detrital zircon sample locations and known fossil localities. X-axis represents erosional profile. Colors represent visual expression of outcrop correlating to paleosol type (Emery-Wetherell et al., 2016). Note that the detrital zircon U-Pb sample identifications listed at the far right do not stratigraphically coincide with the associated fossil localities, which are identified by the bone symbols.

below the fossiliferous horizon. In contrast, the Purple Bench sublocality 19 sample was collected from a tuffaceous sandstone that is located stratigraphically above both the fossiliferous horizon and the Purple Bench tuff. The Rhino's Loaf locality is stratigraphically lower in the DGF section than the other fossil localities sampled for this analysis, but the precise stratigraphic relationships are obscured by local faulting. The Krister Step locality lies within the lower member of the DGF and is stratigraphically below the Purple Bench tuff (Stevens et al., 1984; Wilson, 1986). The Purple Bench 
locality is located $0.3-0.9 \mathrm{~m}$ stratigraphically above the Purple Bench tuff and is one of three key fossil localities occurring near the base of the middle member of the DGF (Stevens et al., 1984). The Peaches locality lies stratigraphically above the Purple Bench locality within the middle member of the DGF, immediately above the "upper red to white repeat" described by Stevens and others (1984).

Zircon fractions were isolated following standard mineral separation techniques (crushing, grinding, water table separation, heavy liquid separation, and magnetic separation). Zircon separates were grain mounted on double-sided adhesive and analyzed using Laser Ablation Inductively Coupled Plasma Mass Spectrometry (LA-ICP-MS) depthprofiling U-Pb analysis at the UTChron Geo-Thermochronology Laboratory. Sixty individual zircon crystals were targeted from each sample for U-Pb analyses in order to obtain a robust statistical coverage of detrital age components present within each sample and to accurately capture the youngest syn-depositional volcanic age component (Vermeesch, 2004; Andersen, 2005; Coutts et al., 2019). The sixty grains analyzed per sample ensures a $95 \%$ confidence of capturing all U-Pb age components that comprise at least $8.5 \%$ of the population distribution (Vermeesch, 2004). LA-ICPMS U-Pb data were processed using the lolitebased VizualAge data reduction scheme with GJ1 zircon as a primary standard for depth-dependent element fractionation correction (Jackson et al., 2004; Paton et al., 2011; Petrus and Kamber, 2012). Detailed methodology and instrument settings for LA-ICP-MS analyses can be found in Thomson and others (2017). Results were excluded from single grain analysis with greater than $15 \%$ discordance between $235 \mathrm{U} / 207 \mathrm{~Pb}$ age and $238 \mathrm{U} / 206 \mathrm{~Pb}$ age and greater than $10 \% 238 \mathrm{U} /$ ${ }^{206} \mathrm{~Pb}$ analytical uncertainty at $2 \mathrm{~s}$ level. Weighted mean ages for the youngest coherent age population were calculated for each sample using the tuff age extractor (TuffZirc) Excel plugin from the ISOPLOT package (Ludwig and Mundil, 2002; Ludwig, 2003). The TuffZirc algorithm was designed for the extraction of a reliable age from primarily deposited tuffs and reworked tuffaceous units. The algorithm automatically excludes ages with high analytical uncertainty, ranks ages in order, and identifies the largest cluster of five or more grains that yield a probability of fit $>0.05$. The calculated TuffZirc age is a median age of the identified largest cluster, the asymmetric error bars represent a 95\% confidence interval of the calculated median age (Ludwig and
Mundil, 2002). TuffZirc requires the assumptions that $>40 \%$ of the ages in the sample are cogenetic and that the majority of ages have not suffered from significant post crystallization lead loss (Ludwig, 2003).

\section{RESULTS}

Detrital zircon $\mathrm{U}-\mathrm{Pb}$ results are displayed in Figure 3 and summarized in Table 2. Full detrital zircon $\mathrm{U}-\mathrm{Pb}$ results are available in the Supplementary data table, including the highly discordant ages that were excluded from weighted mean calculations labeled "DISC" in the "Best Age (Ma)" column. Individual detrital zircon $238 \mathrm{U}-206 \mathrm{~Pb}$ ages with $<10 \%$ analytical uncertainty (2s) and $<15 \%$ discordance between $238 \mathrm{U}-206 \mathrm{~Pb}$ and $235 \mathrm{U}-207 \mathrm{~Pb}$ age were used to calculate weighted means for each sample using the TuffZirc plugin for Excel (Ludwig and Mundil, 2002; Ludwig, 2003). A weighted mean of $45.4+0.6 /-1.1 \mathrm{Ma}$ was calculated from a coherent group of 19 zircons from the 50 analyzed zircons from the Rhino's Loaf locality. The Krister Step locality yielded the fewest zircons during separation $(n=20)$, providing a weighted mean age of $45.5+0.2 /-1.4 \mathrm{Ma}$ from a coherent group of six zircon ages (96.9\% confidence). Fifty-four detrital zircons were analyzed from Purple Bench tuff at sublocality 8 . Individual zircon $238 \mathrm{U}-206 \mathrm{~Pb}$ ages range from $41.1 \pm 0.7 \mathrm{Ma}$ to $49.4 \pm 1.8 \mathrm{Ma}$. The TuffZirc weighted mean calculated was found to be $43.7+0.8 /-0.2 \mathrm{Ma}$ (95\% confidence interval calculated from coherent group of 17). By comparison, a weighted mean of $44.2+0.3 /-0.7 \mathrm{Ma}(95.1 \%$ confidence) was calculated for Purple Bench sublocality 19 from a coherent group of 17 zircons out of the 57 total zircons dated. The Peaches locality yielded a weighted mean age of $42.8+1.0 /-0.4$ $\mathrm{Ma}(95.9 \%$ confidence) calculated from a coherent group of 20 zircon ages out of the total 57 zircons dated.

Eighty percent of the 145 dated grains with < $15 \%$ discordance yield ages ranging from $40-47$ Ma. Three samples contain individual detrital zircon $\mathrm{U}-\mathrm{Pb}$ ages older than $47 \mathrm{Ma}$ in addition to the dominant young syn-depositional zircon U-Pb age component. The Rhino's Loaf sample contains: two grains with ages $>47 \mathrm{Ma}$, one yielding an age of $50.5 \pm 1.3 \mathrm{Ma}$ and the other age of $388.7 \pm 5.0 \mathrm{Ma}$. The Purple Bench sublocality 19 sample contains: 12 grains with ages $>47 \mathrm{Ma}$, two grains with ages from 70-72 Ma, five grains with ages from 81-101 $\mathrm{Ma}$, two grains with ages from 230-260 Ma, two grains with ages from $360-380 \mathrm{Ma}$, and one grain with an age of $1362.7 \pm 8.3 \mathrm{Ma}$. The Peaches sam- 


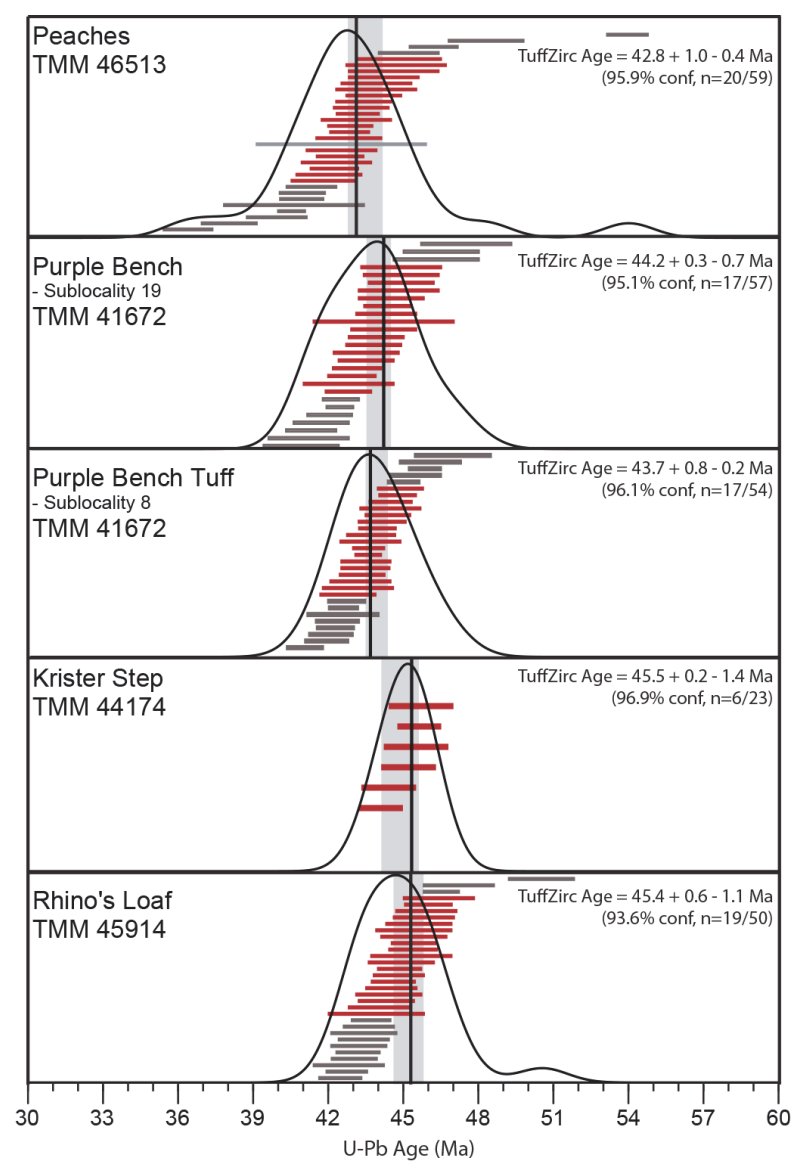

FIGURE 3. Zircon $U-P b$ results from tuffaceous sandstones of the Devil's Graveyard Fm. analyzed via LAICP-MS. Results were filtered to exclude single grain ages with $>15 \%$ discordance between $235 \mathrm{U} / 207 \mathrm{~Pb}$ age and $238 \mathrm{U} / 206 \mathrm{~Pb}$ age, or $>10 \%$ propagated analytical error in $238 \mathrm{U} / 206 \mathrm{~Pb}$ age. Weighted means were calculated for each sample using Tuff extractor plugin from the ISOPLOT package (Ludwig and Mundil, 2002; Ludwig, 2003). Number of grains used in TuffZirc algorithm displayed as $n=$ \# of ages used by TuffZirc / \# of ages total for sample. Data are displayed as kernel density estimators (KDEs) with a bandwidth of $1 \mathrm{Myr}$ (Vermeesch, 2018). Individual zircon ages and 2s standard errors are displayed as vertically stacked boxes. Individual ages in red were used in the calculation of the weighted mean. Weighted means and errors are displayed as a grey box with a bar representing the mean.

ple contains: eight grains with ages $>47 \mathrm{Ma}$, two grains with ages from 54-65 Ma, one grain with an age of $76.0 \pm 2.1 \mathrm{Ma}$, two grains with ages from 97$105 \mathrm{Ma}$, two grains with ages from 395-450 Ma, and one grain with an age of $597.0 \pm 11 \mathrm{Ma}$.

\section{DISCUSSION}

The maximum depositional ages (MDAs) presented herein represent an upper bound estimate of the true depositional ages (TDAs) of these sedimentary horizons and thus the fossils contained within (Dickinson and Gehrels, 2009; Coutts et al., 2019). Following the principle of inclusions (Lyell, 1832), any zircon contained within a sandstone or tuffaceous sandstone must be older than the sandstone or tuffaceous sandstone itself. The time difference between the zircon derived MDA estimate and the TDA incorporates the time required for the zircon to crystalize, erupt from its volcanic center, erode and be transported into the basin before it is deposited. This time lag can be assumed to be negligible (or within analytical uncertainty) in depositional environments located in close proximity to volcanic centers that were active at the time of deposition (Dickinson and Gehrels, 2009).

Given the close proximity of syn-depositionally active volcanic centers, the MDAs presented here are interpreted as the TDAs of the sedimentary strata (Dickinson and Gehrels, 2009; Coutts et al., 2019). A negligible time lag between zircon crystallization and deposition of these sandstones and tuffaceous sandstones is assumed (Dickinson and Gehrels, 2009; Coutts et al., 2019). These zircon grains were most likely derived from volcanic centers in the vicinity of the Tornillo Basin, as evidenced by the high proportion of euhedral zircons composing the youngest coherent age mode and regional geologic studies (Stevens et al., 1984; Runkel, 1990). Further evidence supporting a negligible time lag between zircon crystallization and deposition include the dominance of young ages within the samples, the overlap of the young ages with existing depositional age constrains for the basin, the clustering of young ages indicating a single point source, and the gradual decrease in individual ages and MDAs up-section. While young "syn-depositional" zircon ages dominate all of the samples, several units also yielded subordinate age components older than the syn-depositional ages. These older ages indicate either inheritance within the magma chamber or the reworking of previously deposited tuffs and sandstones during sediment transport and deposition.

The MDA of Purple Bench tuff (TMM 41672) was found to be $43.7+0.8 /-0.2 \mathrm{Ma}$ at sublocality 8. The MDA of the tuffaceous sandstone collected stratigraphically higher than the Purple Bench tuff at sublocality 19 (TMM 41672) is $44.2+0.3 /-0.7$ Ma (Figure 2). Error ranges for the two samples overlap, suggesting that both the Purple Bench tuff 
TABLE 2. Detrital zircon geochronometric results from TuffZirc algorithm (Isoplot; Ludwig, 2003). Full tabulated results of individual zircon $\mathrm{U}-\mathrm{Pb}$ ages are provided in supplementary data files.

\begin{tabular}{|c|c|c|c|c|c|}
\hline \multirow[b]{2}{*}{ Sample Locality } & \multirow{2}{*}{$\begin{array}{l}\text { Total number } \\
\text { zircons dated }\end{array}$} & \multirow{2}{*}{$\begin{array}{l}\text { Number of ages } \\
\text { used in weighted } \\
\text { mean }\end{array}$} & \multirow{2}{*}{$\begin{array}{c}\text { TuffZirc weighted } \\
\text { mean age (Ma) }\end{array}$} & \multicolumn{2}{|c|}{ Error (Ma) } \\
\hline & & & & + & - \\
\hline $\begin{array}{l}\text { Peaches } \\
\text { TMM } 46513\end{array}$ & 59 & 20 & 42.8 & 1.0 & 0.4 \\
\hline $\begin{array}{l}\text { Purple Bench } \\
\text { TMM } 41672 \\
\text { Sublocality } 19\end{array}$ & 57 & 17 & 44.2 & 0.3 & 0.7 \\
\hline $\begin{array}{l}\text { Purple Bench tuff } \\
\text { TMM } 41672 \\
\text { Sublocality } 8\end{array}$ & 54 & 17 & 43.7 & 0.8 & 0.2 \\
\hline $\begin{array}{l}\text { Krister Step } \\
\text { TMM } 44174\end{array}$ & 23 & 6 & 45.5 & 0.2 & 1.4 \\
\hline $\begin{array}{l}\text { Rhino's Loaf } \\
\text { TMM } 45914\end{array}$ & 50 & 19 & 45.4 & 0.6 & 1.1 \\
\hline
\end{tabular}

and the fossils from the Purple Bench locality to have a TDA range of $43.5-44.5 \mathrm{Ma}$. These dates represent the first MDA estimates for the Purple Bench locality and Purple Bench tuff based on detrital zircon $\mathrm{U}-\mathrm{Pb}$, and significantly improve upon the chronostratigraphic precision from prior $\mathrm{K} / \mathrm{Ar}$ radiometric analyses $(41.1-44.7 \mathrm{Ma}$; Stevens et al., 1984; Walton, 1992). An estimated absolute age for the Purple Bench locality between 43.5 44.5 Ma (Figure 4) is consistent with Walton's (1992) interpretations that the fossil assemblage correlated to the C20R-C20N Chron transition (43.43 Ma, recalibrated to GST2012; Gradstein et al., 2012).

The spread in ages between the lower (Rhino's Loaf, $45.4+0.6$ / -1.1 Ma; Krister Step, $45.5+0.2 /-1.4 \mathrm{Ma}$ ) and upper units (Peaches, $42.8+1.0 /-0.4 \mathrm{Ma}$ ) sampled indicates the intervening sediments accumulated over a period of between $0.2-3.1 \mathrm{Myr}$. The absolute ages calculated here for Rhino's Loaf (44.3 - 46.0 Ma) and Krister Step (44.1 - 45.7 Ma) are in good agreement with the sanidine ${ }^{40} \mathrm{Ar} / 39 \mathrm{Ar}$ age estimate $(44.88 \pm 0.04 \mathrm{Ma})$ reported for the Whistler Squat Quarry fossil locality (TMM 41372; Campisano et al., 2014). Like Rhino's Loaf and Krister Step, the Whistler Squat Quarry occurs in the lower member of the DGF (Wilson, 1986), but the relative stratigraphic positions of the three localities are currently unclear. Nevertheless, the detrital zircon dates for Rhino's Loaf and Krister Step indicate that both localities may be broadly contemporaneous with the Whistler Squat Quarry and other early Uintan (Ui1b) localities comprising the Whistler Squat local fauna (Campisano et al., 2014). Furthermore, the range of absolute dates for the DGF reported here (lower date limit for Rhino's Loaf: 46.0 Ma, upper date limit for Peaches: 42.4 Ma) are consistent with the Uintan character of the fauna collected at fossil localities in the lower and middle members of the DGF (Wilson et al., 1986; Williams and Kirk, 2008; Gunnell et al., 2009; Campisano et al., 2014) and with the absolute dates of 46.3 - $41.3 \mathrm{Ma}$ reported by Robinson (2004) for the entire Uintan NALMA.

The magnetostratigraphic studies of the DGF have historically been complicated by multiple interpretations for Chron assignments in the middle member of the DGF (Walton, 1992; Prothero 1996; Murphey et al. 2018). This study brings clarity to the debate of the absolute age of the Purple Bench locality, which has positive implications for defining the Uintan NALMA on a broader, continental level. The absolute ages provided here for the lower and middle members of the DGF allow for better characterization of the late Uintan (Ui3) NALMA and the potential for better correlation between late Uintan localities in Utah, California, Texas, Montana, and Saskatchewan (Robinson et al. 2004). Indeed, with an absolute age range of $43.5-44.5 \mathrm{Ma}$ calculated here for the Purple Bench locality (Ui3) and $44.88 \pm 0.04 \mathrm{Ma}$ calculated by Campisano et al. (2014) for the Whistler Squat Quarry (Ui1b), the Ui1/Ui2 transition (marked by the first appearance of a range of taxa, including artiodactyls Achaenodon, Bunomeryx, Diplobunops, Leptotragulus, and Mesomeryx; Gunnell et al., 2009) is increasingly constrained to a relatively narrow time interval. The best estimate for the TDA for the Purple Bench locality based on the calculated MDA ages presented herein, and the Ui3 fauna collected at the Purple Bench locality is $43.5-44.5 \mathrm{Ma}$. If so, then classic Ui2 assemblages known from other regions 


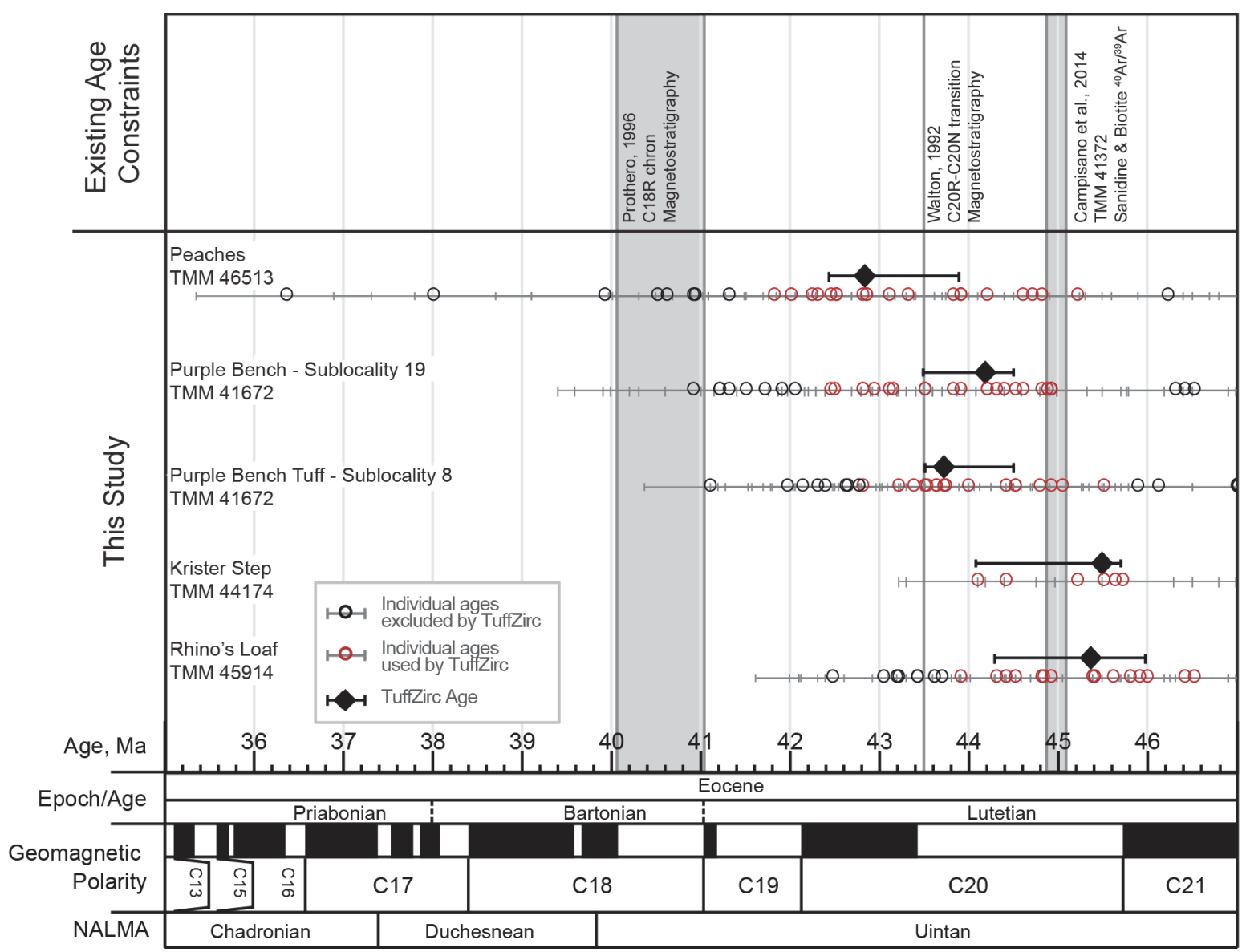

FIGURE 4. Comparison of new and published age estimates for the Devil's Graveyard Fm. and the Purple Bench tuff. Walton (1992) placed the Purple Bench tuff at the C20R-C20N chron transition (43.43 Ma; recalibrated to GST2012; Gradstein et al., 2012), while Prothero (1996) placed the Purple Bench tuff within the C18R chron (41.15- 40.14 Ma; recalibrated to GST2012; Gradstein et al., 2012).

of North America (e.g., the White River Pocket sample from the Uinta Basin of Utah; Gunnell et al., 2009) probably date to between 43.5 and $44.9 \mathrm{Ma}$.

\section{CONCLUSIONS}

Here we report the first absolute dates for the lower and middle members of the DGF based on detrital zircon $\mathrm{U}-\mathrm{Pb}$ geochronology. The maximum depositional age calculated for the Purple Bench locality $(43.5-44.5 \mathrm{Ma})$ constrains the absolute age of the late Uintan NALMA (Ui3) within the Tornillo Basin. The stratigraphically lower Krister Step and Rhino's Loaf fossil localities in the lower member of the DGF have an absolute age range of 44.1 - 45.7 Ma and 44.3 - 46.0 Ma, respectively. The stratigraphically higher Peaches locality in the middle member of the DGF has an absolute age range of $42.4-43.9 \mathrm{Ma}$. These new U-Pb data are consistent with prior radiometric dates for the DGF and the Uintan character of the fauna recovered from these fossil localities. These new dates provide further evidence supporting magnetostratigraphic age models placing the lower and middle members of the DGF at the C20R and C20N Chron transition. These chronostratigraphic constraints aid the characterization of the temporally and spatially variable Uintan land mammal age.

\section{ACKNOWLEDGMENTS}

We thank J. Clarke and her Geo 371T course for feedback on earlier versions of this manuscript, specifically A. Papendieck, S. Davis, and J. Proffitt. Thanks to S. Egberts and I. Lundeen for field assistance, and L. Stockli for LA-ICP-MS analytical assistance. We thank R. Willis, W. Cook, N. Horner, and Midwestern State University for assistance with field logistics and for access to Dalquest Desert Research Site. Thanks to C. Campisano, A. Cole, E. Davis, P. Murphey, and B. Townsend for discussion. We acknowledge J. Stevens, M. Ste- 
vens, J. Wilson, B. Rainey, and the other geologists and paleontologists who made this work possible through their foundational research on the Devil's Graveyard Formation. This work was partially funded by an NSF Graduate Research Fel- lowship for A.L. Atwater, an Equinor Fellowship for K.D. Thomson, a Billy Carr Fellowship to E.C. Kirk, a Thomas Condon Fellowship for M. EmeryWetherell, and funds from the UTchron facility and the Jackson School of Geosciences.

\section{REFERENCES}

Andersen, T. 2005. Detrital zircons as tracers of sedimentary provenance: limiting conditions from statistics and numerical simulation. Chemical Geology, 216:249-270. https://doi.org/ 10.1016/j.chemgeo.2004.11.013

Campisano, C.J., Kirk, E.C., Townsend, K.B., and Deino, A.L. 2014. Geochronological and taxonomic revisions of the middle Eocene Whistler Squat Quarry (Devil's Graveyard Formation, Texas) and implications for the early Uintan in Trans-Pecos Texas. PloS One, 9:e101516. https://doi.org/10.1371/journal.pone.0101516

Coutts, D.S., Matthews, W.A., and Hubbard, S.M. 2019. Assessment of widely used methods to derive depositional ages from detrital zircon populations. Geoscience Frontiers, 10:14211435. https://doi.org/10.1016/j.gsf.2018.11.002

Dickinson, W.R. and Gehrels, G.E. 2009. Use of U-Pb ages of detrital zircons to infer maximum depositional ages of strata: a test against a Colorado Plateau Mesozoic database. Earth and Planetary Science Letters, 288:115-125. https://doi.org/10.1016/j.epsl.2009.09.013

Emery-Wetherell, M.M., Atwater, A., Thomson, K., Wetherell, L.R., Kirk, E.C., and Stockli, D.F. 2016. Paleoenvironment reconstruction and geochronology of the lower and middle members of the Devil's Graveyard Formation (Tornillo Basin, Texas). Geological Society of America Abstracts with Programs, 48:74-22. https://doi.org/10.1130/abs/2016AM-284354

Gradstein, F.M., Ogg, J.G., Schmitz, M., and Ogg, G. 2012. Geologic Time Scale 2012. Elsevier, Oxford, Netherlands. https://doi.org/10.1016/c2011-1-08249-8

Gunnell, G.F., Murphey, P.C., Stucky, R.K., Townsend, K.B., Robinson, P., Zonneveld, J.P., Bartels, W.S., and Albright III, L.B. 2009. Biostratigraphy and biochronology of the latest Wasatchian, Bridgerian, and Uintan North American land mammal "ages." Papers on Geology, Vertebrate Paleontology, and Biostratigraphy in Honor of Michael O. Woodburne. Museum of Northern Arizona Bulletin, 65:279-330.

Gustafson, E.P. 1986. Carnivorous mammals of the late Eocene and early Oligocene of TransPecos Texas. Texas Memorial Museum, 33:1-66.

Henry, C.D. and Price, J.G. 1989. The Christmas Mountains caldera complex, Trans-Pecos Texas. Bulletin of Volcanology, 52:97-112. https://doi.org/10.1007/BF00301549

Jackson, S.E., Pearson, N.J., Griffin, W.L., and Belousova, E.A. 2004. The application of laser ablation-inductively coupled plasma-mass spectrometry to in situ U-Pb zircon geochronology. Chemical Geology, 211:47-69.

Johnstone, S.A., Schwartz, T.M., and Holm-Denoma, C.S. 2019. A stratigraphic approach to inferring depositional ages from detrital geochronology data. Frontiers in Earth Science, 7:119. https://doi.org/10.3389/feart.2019.00057

Kirk, E.C. 2018. New Eocene primates from the Tornillo Basin of Trans-Pecos Texas. American Journal of Physical Anthropology, 66:140.

Kirk, E.C. and Williams, B.A. 2011. New adapiform primate of Old World affinities from the Devil's Graveyard Formation of Texas. Journal of Human Evolution, 61:156-168. https://doi.org/ 10.1016/j.jhevol.2011.02.014

Lawton, T.F., Bradford, I.A., Vega, F.J., Gehrels, G.E., and Amato, J.M. 2009. Provenance of Upper Cretaceous-Paleogene sandstones in the foreland basin system of the Sierra Madre Oriental, northeastern Mexico, and its bearing on fluvial dispersal systems of the Mexican Laramide Province. Geological Society of America Bulletin, 121:820-836. https://doi.org/ 10.1130/B26450.1

Lehman, T.M. 1991. Sedimentation and tectonism in the Laramide Tornillo Basin of West Texas. Sedimentary Geology, 75:9-28. https://doi.org/10.1016/0037-0738(91)90047-H 
Lehman, T.M., Wick, S.L., Beatty, H.L., Straight, W.H., and Wagner, J.R. 2018. Stratigraphy and depositional history of the Tornillo Group (Upper Cretaceous-Eocene) of West Texas. Geosphere, 14:2206-2244. https://doi.org/10.1130/GES01641.1

Ludwig, K.R. 2003. User's Manual for Isoplot 3.00: A Geochronological Toolkit for Microsoft Excel. Kenneth R. Ludwig.

Ludwig, K.R. and Mundil, R. 2002. Extracting reliable U-Pb ages and errors from complex populations of zircons from Phanerozoic tuffs. Geochimica et Cosmochimica Acta, 66:A463463.

Murphey, P.C., Kelly, T.S., Chamberlain, K.R., Tsukui, K., and Clyde, W.C. 2018. Mammals from the earliest Uintan (middle Eocene) Turtle Bluff Member, Bridger Formation, southwestern Wyoming, USA, Part 3: Marsupialia and a reevaluation of the Bridgerian-Uintan North American Land Mammal Age transition. Palaeontologia Electronica, 21.2.25A:1-52. https:// doi.org/10.26879/804

Nieto-Samaniego, Á.F., Ferrari, L., Alaniz-Alvarez, S.A., Labarthe-Hernández, G., and RosasElguera, J. 1999. Variation of Cenozoic extension and volcanism across the southern Sierra Madre Occidental volcanic province, Mexico. Geological Society of America Bulletin, 111:347-363. https://doi.org/10.1130/0016-7606(1999)111<0347:VOCEAV>2.3.CO;2

Paton, C., Hellstrom, J., Paul, B., Woodhead, J., and Hergt, J. 2011. lolite: freeware for the visualisation and processing of mass spectrometric data. Journal of Analytical Atomic Spectrometry, 26:2508-2518. https://doi.org/10.1039/c1ja10172b

Petrus, J.A. and Kamber, B.S. 2012. VizualAge: a novel approach to laser ablation ICP-MS U-Pb geochronology data reduction. Geostandards and Geoanalytical Research, 36:247-270. https://doi.org/10.1111/j.1751-908X.2012.00158.x

Prothero, D.R. 1996. Magnetostratigraphy of the Eocene-Oligocene Transition in Trans-Pecos Texas, p. 189-198. In Prothero, D.R. and Emry, R.J. (eds.), The Terrestrial EoceneOligocene Transition in North America. Cambridge University Press, Cambridge.

Prothero, D.R. and Berggren, W.A. 2014. Eocene-Oligocene Climatic and Biotic Evolution. Princeton University Press, Princeton, New Jersey.

Robinson, P., Gunnell, G.F., Walsh, S.L., Clyde, W.C., Storer, J.E., Stucky, R.K., Froehlich, D.J., Ferrusquia-Villafranca, I., McKenna, M.C., and Woodburne, M.O. 2004. Wasatchian through Duchesnean biochronology, p. 106-155. In Woodburne, M. (ed.), Late Cretaceous and Cenozoic Mammals of North America: Biostratigraphy and Geochronology. Columbia University Press, New York. https://doi.org/10.7312/wood13040-006

Runkel, A.C. 1990. Stratigraphy and depositional history of Late Cretaceous and Paleogene rocks, Trans-Pecos Texas, p. 117-146. In Dickerson, P.W., Stevens, M.S., and Stevens, J.B. (eds.), Geology of the Big Bend, and Trans-Pecos, Texas. Fieldtrip Guidebook of the South Texas Geological Society.

Stevens, J.B., Stevens, M.S., and Wilson, J.A. 1984. Devil's Graveyard Formation (new) Eocene and Oligocene Age Trans-Pecos Texas. Texas Memorial Museum, 32:1-20.

Stocker, M.R. and Kirk, E.C. 2016. The first amphisbaenians from Texas, with notes on other squamates from the middle Eocene Purple Bench locality. Journal of Vertebrate Paleontology, 36:1-15. https://doi.org/10.1080/02724634.2016.1094081

Swanson, E.R. and McDowell, F.W. 1984. Calderas of the Sierra Madre Occidental volcanic field western Mexico. Journal of Geophysical Research: Solid Earth, 89:8787-8799. https:// doi.org/10.1029/JB089iB10p08787

Thomson, K.D., Stockli, D.F., Clark, J.D., Puigdefàbregas, C., and Fildani, A. 2017. Detrital zircon $(\mathrm{U}-\mathrm{Th}) /(\mathrm{He}-\mathrm{Pb})$ double-dating constraints on provenance and foreland basin evolution of the Ainsa Basin, south-central Pyrenees, Spain: Ainsa Basin Zircon Double Dating. Tectonics, 36:1352-1375. https://doi.org/10.1002/2017TC004504

Vermeesch, P. 2004. How many grains are needed for a provenance study? Earth and Planetary Science Letters, 224:441-451. https://doi.org/10.1016/j.epsl.2004.05.037

Vermeesch, P. 2018. September. IsoplotR: a free and open toolbox for geochronology. Geoscience Frontiers, 9:1479-1493. https://doi.org/10.1016/j.gsf.2018.04.001

Walton, A. 1992. Magnetostratigraphy and geochronology of the lower and middle members of the Devil's Graveyard Formation (middle Eocene), Trans-Pecos Texas, p. 74-87. Eocene-

Oligocene Climatic and Biotic Evolution. Princeton University Press, Princeton, New Jersey.

Walton, A.H. 1993. Pauromys and other small Sciuravidae (Mammalia: Rodentia) from the Middle Eocene of Texas. Journal of Vertebrate Paleontology, 13:243-261. https://doi.org/ 10.1080/02724634.1993.10011503 
West, R.M. 1982. Fossil mammals from the lower Buck Hill Group, Eocene of Trans-Pecos Texas: Marsupicarnivora, Primates, Taeniodonta, Condylarthra, bunodont Artiodactyla, and Dinocerata. Texas Memorial Museum, 35:1-18.

Williams, B.A. and Kirk, E.C. 2008. New Uintan primates from Texas and their implications for North American patterns of species richness during the Eocene. Journal of Human Evolution, 55:927-941. https://doi.org/10.1016/j.jhevol.2008.07.007

Wilson, J.A. 1986. Stratigraphic occurrence and correlation of early Tertiary vertebrate faunas, Trans-Pecos Texas: Agua Fria-Green Valley areas. Journal of Vertebrate Paleontology, 6:350-373. https://doi.org/10.1080/02724634.1986.10011630

Wilson, J.A. and Stevens, M.S. 1986. Fossil vertebrates from the latest Eocene, Skyline channels, Trans-Pecos Texas. Rocky Mountain Geology, 24:221-235. https://doi.org/ 10.2113/gsrocky.24.special_paper_3.221 


\section{SUPPLEMENTARY DATA}

Full zircon U-Pb geochronometric results of all grains analyzed from the Devil's Graveyard Formation. Individual zircon $238 \mathrm{U}-206 \mathrm{~Pb}$ ages with $>10 \%$ analytical uncertainty $(2 \mathrm{~s})$ or $>15 \%$ discordance between $238 \mathrm{U}-206 \mathrm{~Pb}$ and $235 \mathrm{U}-207 \mathrm{~Pb}$ age were excluded from TuffZirc weighted mean calculations. All analyses were conducted at the UTchron laboratory at the University of Texas at Austin.

A zipped spreadsheet file available at https://palaeo-electronica.org/content/2020/2898-devil-sgraveyard-u-pb-dating 